\title{
Wpływ pandemii COVID-19 na sytuację finansową i funkcjonowanie jednostek samorządu terytorialnego
}

\section{Katarzyna Kostyk-Siekierska}

\author{
Uniwersytet Ekonomiczny \\ we Wrocławiu \\ E-mail: \\ katarzyna.kostyk-siekierska@ue.wroc.pl \\ ORCID: 0000-0001-6819-0355
}

\begin{abstract}
Abstrakt: Recesja wywołana pandemią COVID-19 i lockdownem była głównym czynnikiem wpływającym na sytuację finansową jednostek samorządu terytorialnego w 2020 r. Epidemia postawiła przed jednostkami samorządu terytorialnego szereg wyzwań i spowodowała konieczność szybkiego dostosowania ich funkcjonowania do nowej rzeczywistości. Celem artykułu jest ocena wpływu pandemii na funkcjonowanie jednostek samorządu terytorialnego (JST) i ich sytuację finansową. Przedstawiono problemy wynikające $\mathrm{z}$ wprowadzanego i zmienianego w wyniku pandemii ustawodawstwa dotyczącego funkcjonowania JST, a także wpływ pandemii na ich dochody i wydatki. Do oceny zmian sytuacji finansowej JST zastosowano metodę analizy porównawczej. Za podstawę analiz przyjęto wielkości dochodowe, wydatkowe oraz wynikowe za lata 2018-2020 oraz ich porównanie z planami. Głównym źródłem danych są wielkości zbiorcze dostępne na stronie www.mf.gov.pl, na które składają się zestawienia zbiorcze z wykonania budżetów JST po czterech kwartałach za lata 2018, 2019 i 2020, uzupełnione w niektórych kwestiach odwołaniem do sprawozdań z wykonania budżetów Rb27s (dochody) i Rb28s (wydatki).
\end{abstract}

Słowa kluczowe: jednostki samorządu terytorialnego, sytuacja finansowa, finanse publiczne, pandemia COVID-19

\section{Wprowadzenie}

Recesja wywołana rozprzestrzenianiem się koronawirusa SARS-CoV-2 w świecie i rosnąca liczba zachorowań na wywoływaną przez niego chorobę o nazwie COVID-19 była jednym z głównych czynników wpływających na sytuację finansową jednostek samorządu terytorialnego w ubiegłym roku. Epidemia postawiła przed jednostkami samorządu terytorialnego szereg wyzwań i spowodowała konieczność szybkiego dostosowania ich funkcjonowania do nowej rzeczywistości. Działania przeciwepidemiczne i zapobiegawcze, których celem było zminimalizowanie skutków epidemii dotyczyły m.in.: zawieszenia zajęć w szkołach i na uczelniach,
Publikacja sfinansowana przez: Małopolska Wyższa Szkoła Ekonomiczna w Tarnowie

Korespondencja:

Katarzyna Kostyk-Siekierska

Uniwersytet Ekonomiczny

we Wrocławiu,

ul. Komandorska 118/120,

53-345 Wrocław

Tel.: 888102 902, 713680384 
czasowego ograniczenia różnych sposobów przemieszczania się, czasowego ograniczenia funkcjonowania określonych instytucji i zakładów pracy, zakazu organizowania widowisk i innych zgromadzeń ludności, a także różnych form dystansowania społecznego. Wprowadzone ograniczenia spowodowały, że wiele gałęzi polskiej gospodarki zmuszonych zostało do reorganizacji, a często czasowego zawieszenia swojej działalności. Podobnie samorządy zmuszone zostały do podjęcia działań polegających na reorganizacji ich funkcjonowania, a także ponoszenia dodatkowych kosztownych działań mających na celu minimalizację negatywnych skutków pandemii. Samorządy musiały dokonać dodatkowych wydatków m.in.: na opiekę zdrowotną, opiekę nad osobami starszymi, pomoc dla przedsiębiorców, wsparcie szkół czy zakup środków do dezynfekcji.

Celem artykułu jest ocena wpływu pandemii na funkcjonowanie i finanse jednostek samorządu terytorialnego (JST). Odpowiedź na pytanie, w jaki sposób pandemia wpłynęła na sytuację finansową JST, nie jest jednak prosta. Wynika to z faktu, że wciąż jesteśmy w trakcie pandemii oraz końca kolejnego lockdownu. Oceniając sytuację samorządów należy uwzględnić wpływ wprowadzanych i bez przerwy zmienianych w wyniku pandemii przepisów dotyczących funkcjonowania JST. Epidemia wpłynęła na budżety samorządów, które zostały uszczuplone przez zmniejszenie dochodów z PIT, CIT, podatków od nieruchomości, opłat czynszowych, czy też opłat związanych z korzystaniem z komunikacji miejskiej przez mieszkańców oraz stref płatnego parkowania. $Z$ powodu braku odpowiednich podziałek klasyfikacji budżetowej i bez osobnych badań ankietowych nie da się dokładnie ustalić wysokości wydatków poniesionych przez JST na przeciwdziałanie skutkom pandemii. Trudno również rozdzielić wpływ zmian cyklu koniunkturalnego od następstw pandemii. Do marca 2021 r. dysponowaliśmy tylko danymi kwartalnymi za pierwsze trzy kwartały 2020 r. Dane kwartalne ciężko było porównywać z okresami wcześniejszymi, ze względu na równoczesne podejmowanie licznych działań, takich jak: przesunięcia terminów wpływów podatkowych, ciągłe zmiany przepisów, wprowadzanie kolejnych tarcz antykryzysowych, następujące po sobie lockdowny i poluzowania będące efektem kolejnych fal zakażeń na przemian z poprawą sytuacji, zmiany zachowań ludzi i reakcji przedsiębiorstw na kolejne obostrzenia, czy w końcu różne opóźnienia efektów zdarzeń w stosunku do momentu ich wystąpienia. Od marca 2021 r. dostępne są dane za czwarty kwartał, czyli cały rok 2020. Dane te umożliwiają dokładniejszą analizę wpływu pandemii na sytuację JST (zamknięte budżety roczne). Pamiętać jednak należy o tym, że na te dane wpływa również zmieniająca się polityka władz centralnych wobec JST, co razem z opisanymi wyżej czynnikami utrudnia ocenę wpływu pojedynczego czynnika, co widać w zróżnicowanych ocenach ekspertów.

\section{Metodologia badania}

Do oceny zmian sytuacji finansowej JST zastosowano metodę analizy porównawczej. Dokonano porównania wielkości dochodowych, wydatkowych oraz wynikowych. Za podstawę analiz przyjęto porównanie wyników za 2020 r. z analogicznym okresem w latach poprzednich (głównie za lata 2018-2019). Analiza polegała również na porównaniu rzeczywistego stanu z wielkościami prognozowanymi w budżetach JST. Za podstawę analiz służą w głównej mierze dane zbiorcze dostępne na stronie www.mf.gov.pl: zestawienia zbiorcze z wykonania budżetów JST po czterech 
kwartałach lat 2018, 2019 i 2020, uzupełnione w niektórych kwestiach odwołaniem do sprawozdań z wykonania budżetów Rb27s (dochody) i Rb28s (wydatki). Zaprezentowano ogólną sytuację finansową jednostek samorządu terytorialnego dokonaną w oparciu o osiągnięte dochody i wydatki (bieżące i majątkowe) ujęte w sprawozdaniach sporządzonych przez jednostki samorządowe w latach 2018-2019 i porównano wyniki z rokiem wystąpienia epidemii, czyli rokiem 2020.

W artykule zwrócono uwagę na problemy związane z wpływem pandemii, na funkcjonowanie jednostek samorządu terytorialnego. Przedstawiono zagadnienia dotyczące ustawodawstwa wydawanego w celu przeciwdziałania epidemii COVID-19 i jej skutkom, a także problemy wpływające na sytuację finansową JST. Wyniki zaprezentowano zarówno w ujęciu zbiorczym jak i dla mniejszych grup:
a)gmin,
b)powiatów,
c)miast na prawach powiatu,
d)samorządów wojewódzkich.

\section{Ustawodawstwo w okresie pandemii COVID-19 a funkcjonowanie JST}

Ustawodawstwo wydawane w celu przeciwdziałania pandemii COVID-19 i jej skutkom, w tym skutkom wprowadzonych na jego podstawie restrykcji, w szczególności tzw. lockdownu - zapoczątkowane zostało ustawą z dnia 2 marca 2020 r. o szczególnych rozwiązaniach związanych z zapobieganiem, przeciwdziałaniem i zwalczaniem COVID-19, innych chorób zakaźnych oraz wywołanych nimi sytuacji kryzysowych wywarło zarówno pośredni, jak i bezpośredni wpływ na funkcjonowanie jednostek samorządu terytorialnego. ${ }^{1}$. Ustawa ta zmieniana była w przeciągu roku ponad 40 razy. Łącznie w 2020 r. wydano 15 ustaw i około 200 uchwał i rozporządzeń dotyczących COVID-192. Akty te bezpośrednio lub pośrednio wpłynęły na funkcjonowanie $\mathrm{JST}^{3}$. Ustawodawstwo okresu pandemii dotyczące JST można podzielić na kilka kategorii (Nelicki, 2020):

1.Przepisy odnoszące się wprost do JST, które miały ułatwić ich funkcjonowanie podczas kryzysu związanego z pandemią. Dotyczą one przede wszystkim rozluźnienia reguł fiskalnych, a także pozyskania dodatkowych wpływów do budżetu, m.in.:

- wprowadzenia w 2020 r. możliwości nierównowagi strony bieżącej budżetu JST dodatkowo o wartość planowanego ubytku w dochodach (z podatku dochodowego od osób fizycznych, podatku dochodowego od osób prawnych, podatków lokalnych: od nieruchomości, rolnego, leśnego, od środków transportowych, podatku od czynności cywilno-prawnych, opłat lokalnych: skarbowej, uzdrowiskowej i miejscowej) będącego skutkiem wystąpienia COVID-19,

${ }^{1} \mathrm{Na}$ skalę, złożoności, niejednorodności, a także chaotyczności tego ustawodawstwa wskazuje, przygotowane dla forum Idei, opracowanie Izdebskiego, 2020.

${ }^{2}$ Listę ustaw wydanych w związku z COVID-19 zawarto w spisie literatury.

${ }^{3}$ Zgodnie z ustaleniami firmy Grant Thornton tylko do końca czerwca 2020 r. wydano 10 ustaw i 188 rozporządzeń dotyczących COVID-19. Z czego 53\% objętości aktów prawnych dotyczyło bezpośrednio działalności przedsiębiorstw, natomiast 35\% - zasad funkcjonowania organów władz publicznych, a reszta, problematyki spoza obszaru pandemii. Ustawy te wyznaczały bezpośrednio lub pośrednio zadania podmiotów publicznych, zarówno organów państwowych jak i samorządu terytorialnego. 
- złagodzenia w 2020 r. reguły fiskalnej ograniczającej zadłużenie o kwotę faktycznego ubytku w dochodach podatkowych jednostki wynikającego z wystąpienia epidemii,

- wprowadzenia możliwości przekazywania w 2020 r. rat części oświatowej, wyrównawczej, równoważącej i regionalnej subwencji ogólnej w terminach wcześniejszych,

- wprowadzenia możliwości przesunięcia na kolejne miesiące wpłat z tytułu tzw. ,janosikowego", czyli wpłat do budżetu państwa dokonywanych przez jednostki samorządu terytorialnego, których dochody podatkowe przekraczają ustawowy wskaźnik na drugie półrocze $2020 \mathrm{r}$.,

- zwiększenia dochodów samorządu powiatowego z tytułu gospodarowania nieruchomościami Skarbu Państwa z 25\% do 50\% wpływów w okresie maj-grudzień 2020 r.,

- uelastycznienia wydatkowania środków z tzw. funduszu korkowego w 2020 r. (na przeciwdziałanie i profilaktykę uzależnień od alkoholu oraz przeciwdziałanie narkomanii) - możliwość przeznaczenia środków na działania związane z zapobieganiem, przeciwdziałaniem i zwalczaniem COVID-19 oraz wywołanych nim sytuacji kryzysowych,

- możliwość zwiększenia zadłużenia poprzez wyłączenie ze spłaty zobowiązań zaciągniętych w $2020 \mathrm{r}$. związanych z uzupełnieniem ubytku w dochodach podatkowych jednostki samorządu terytorialnego wynikającego z wystąpienia epidemii,

- zapis wzmacniający bezpieczeństwo finansowe jednostek samorządu terytorialnego w postaci obowiązującego w 2020 r. jednorocznego limitu długu na poziomie $80 \%$ dochodów danej jednostki,

- pokrycia części kosztów związanych z wydawaniem decyzji o warunkach zabudowy zwiększając opłatę skarbową za wydawanie tej decyzji dla osób innych niż właściciel lub użytkownik wieczysty,

- wydłużenia zezwoleń na sprzedaż napojów alkoholowych o 6 miesięcy, jeżeli wygasały w okresie stanu epidemii.

2. Przepisy nakładające na samorządy i ich jednostki organizacyjne obowiązki dotyczące przeciwdziałania pandemii. Finansowe skutki tych przepisów są trudne do uchwycenia, ponieważ nie zdecydowano się - mimo postulatów formułowanych przez samorządy - na uzupełnienie klasyfikacji budżetowej o podziałki umożliwiające identyfikację tego typu wydatków.

3. Przepisy określające zasady wprowadzenia lockdownu. Część z nich nie była skierowana do samorządów lub obejmowała je na zasadach analogicznych do innych podmiotów. Wśród tych przepisów znajdowały się również te dotyczące wprost działalności podmiotów samorządowych, jak np. zawieszenie stacjonarnych zajęć szkolnych czy ograniczenia liczby pasażerów w transporcie lokalnym. Przepisy te w zasadniczy sposób wpłynęły na stan finansów jednostek samorządu terytorialnego, ograniczając działalność gospodarczą i wywołując recesję, a w konsekwencji zmniejszenie wpływów z podatków. W niektórych przypadkach mogły też powodować oszczędności (koszty utrzymania obiektów, mediów i utrzymania czystości w zamkniętych szkołach), które jednak są wyjątkiem i w niewielkiej skali na tle tych, które generowały dodatkowe wydatki dla samorządów. 
4. Przepisy stanowiące finansowe wsparcie JST przez państwo. Utworzono Rządowy Fundusz Inwestycji Lokalnych (RFIL), którego celem było umożliwienie JST pozyskania środków na realizację zadań inwestycyjnych z Funduszu Środków Przeciwdziałania COVID-19. Środki z RFIL przeznaczono na dotacje dla gmin, powiatów i miast, które mały trudności finansowe, w tym wskutek epidemii. Mogły one zostać wykorzystane na bliskie ludziom inwestycje, m.in.: remonty szkół i przedszkoli, inwestycje w wodociągi i kanalizację, budowę żłobków, dróg, a także inne niezbędne lokalnie działania. W sumie na wsparcie JST przeznaczono ponad 13 mld złotych:

- 6 mld zł - środki, które trafiły latem 2020 r. do wszystkich gmin i powiatów w całej Polsce (wsparcie wyliczone przez algorytm);

- 4,35 mld zł - środki przyznane jednostkom samorządu terytorialnego w ramach konkursu;

- 1,65 mld zł - środki przyznawane jednostkom samorządu terytorialnego w ramach drugiego konkursu;

- dodatkowa pula $250 \mathrm{mln}$ zł skierowana dla gmin popegeerowskich;

-1 mld zł skierowany do gmin górskich z przeznaczeniem na zakupy inwestycyjne lub inwestycje w ogólnodostępną infrastrukturę turystyczną oraz w infrastrukturę komunalną związaną z usługami turystycznymi.

\section{Wpływ pandemii na stan finansowy JST}

\subsection{Ogólna sytuacja finansowa sektora samorządowego}

Polskie samorządy już od dłuższego czasu zmagają się z problemami finansowymi, które poważnie rzutują na ich budżety. W 2020 r. dwa wydarzenia miały szczególne znaczenie dla stanu finansów samorządowych. Pierwszym jest oczywiście pandemia koronawirusa, która zmusiła JST do zwiększenia wydatków na opiekę zdrowotną, wsparcie lokalnych biznesów i mieszkańców. Drugim było wejście w życie zmian w przepisach dotyczących podatku PIT (obniżenie stawek z 18\% do 17\% oraz wprowadzenie zerowego PIT-u dla osób poniżej 26 roku życia), które miały bezpośredni wpływ na zmniejszenie samorządowych dochodów. Dlatego wielu działaczy samorządowych, ekspertów i analityków zapowiadało poważny deficyt w lokalnych budżetach i oceniało, że sytuacja JST znacznie się pogorszy w $2020 \mathrm{r}$. Natomiast dane zbiorcze opublikowane przez Ministerstwo Finansów (MF) prezentują, jak się wydaje, dobrą sytuację finansową samorządów i tak są komentowane przez władze centralne. Rodzi się w tej sytuacji pytanie: jak rzeczywiście wygląda sytuacja finansowa samorządów?

Według danych ze sprawozdań za IV kwartały 2020 r., zaprezentowanych przez MF budżety JST zamknęły się zbiorczo nadwyżką w kwocie $5.689 \mathrm{mln}$ zł, przy planowanym deficycie w wysokości $21.170 \mathrm{mln}$ zł. W 2020 r. JST osiągnęły dochody ogółem w łącznej kwocie $304.930 \mathrm{mln}$ zł (tj. 100,4\% planu). Łączna kwota wydatków JST wyniosła $299.241 \mathrm{mln}$ zł, co stanowiło $92,1 \%$ kwoty wydatków planowanych. Natomiast dochody bieżące były wyższe niż wykonane wydatki bieżące o $21.384 \mathrm{mln}$ zł. 
Tabela 1. Wykonanie budżetów JST w latach 2018-2020. Podstawowe wielkości

\begin{tabular}{|c|c|c|c|c|c|c|c|}
\hline \multirow{3}{*}{ Wyszczególnienie } & \multicolumn{3}{|c|}{ Wykonanie } & \multicolumn{2}{|c|}{ Zmiana wartościowo } & \multicolumn{2}{|c|}{ Zmiana procentowo } \\
\hline & 2018 & 2019 & 2020 & $2019 / 2018$ & $2020 / 2019$ & $2019 / 2018$ & $2020 / 2019$ \\
\hline & \multicolumn{3}{|c|}{ w mln zł } & \multicolumn{2}{|c|}{$\mathrm{w}$ mln $\mathrm{zl}$} & \multicolumn{2}{|c|}{$\mathrm{w} \%$} \\
\hline 1 & 2 & 3 & 4 & 5 (kol. 3-2) & 6 (kol. 4-3) & 7 (kol. 5/2) & 8 (kol. 6/3) \\
\hline I. Dochody ogółem & 251846 & 278507 & 304930 & 26661 & 26423 & 10,6 & $\mathbf{9 , 5}$ \\
\hline I.1. Dochody bieżące & 229630 & 253312 & 271873 & 23682 & 18561 & 10,3 & 7,3 \\
\hline I.2. Dochody majątkowe & 22216 & 25195 & 33057 & 2979 & 7862 & 13,4 & 31,2 \\
\hline II. Wydatki ogólem & 259386 & 280209 & 299241 & 20823 & 19032 & 8,0 & 6,8 \\
\hline II.1. Wydatki bieżące & 206508 & 229157 & 250489 & 22648 & 21332 & 11,0 & 9,3 \\
\hline II.2. Wydatki majątkowe & 52878 & 51052 & 48752 & -1826 & -2301 & $-3,5$ & $-4,5$ \\
\hline w tym inwestycyjne & 51023 & 48974 & 46633 & -2049 & -2340 & $-4,0$ & $-4,8$ \\
\hline III. Wynik ogółem & -7540 & -1702 & 5689 & 5838 & 7391 & $-77,4$ & $-434,3$ \\
\hline III.1. Wynik operacyjny & 23122 & 24156 & 21384 & 1034 & -2771 & 4,5 & $-11,5$ \\
\hline III.2. Wynik majątkowy & -30662 & -25857 & -15695 & 4804 & 10163 & $-15,7$ & $-39,3$ \\
\hline Zadłużenie ogółem & 76116 & 82036 & 89845 & 5920 & 7809 & 7,8 & 9,5 \\
\hline
\end{tabular}

Źródło: Opracowanie własne na podstawie danych opublikowanych na stronach Ministerstwa Finansów (2020).

Sytuacja sektora finansów publicznych w ujęciu zbiorczym po roku pandemii i dwóch lockdownach w 2020 r. nie wygląda, w porównaniu do lat poprzednich, katastrofalnie, tak jak zapowiadali to liczni eksperci w swoich raportach (Swianiewicz, Łukomska, 2020a, 2020b; Folczak, Gołaszewski, 2020). Samorządy zamknęły rok 2020 nadwyżką budżetową w wysokości 5,6 mld zł, natomiast w 2019 r. i 2018 r. budżety jednostek samorządu terytorialnego zamknęły się deficytem w wysokości odpowiednio 1,7 mld zł i 7,5 mld zł. Łączne dochody JST w 2020 r. wzrosły w stosunku do roku poprzedniego o $26,4 \mathrm{mld}$ zł (9,5\%), natomiast łączne wydatki wzrosły o 19,0 mld zł (6,8\%). Jak to możliwe? Czy dodatni wynik budżetów świadczy o tym, że sytuacja samorządów ostatecznie okazała się korzystna mimo kryzysu?

Według M. Gołaszewskiego sytuacja JST wyglądałaby zupełnie inaczej, gdyby nie Rządowy Fundusz Inwestycji Lokalnych (RFIL), który dotował w 2020 r. samorządy kwotą w wysokości 10,3 mld zł. Ta suma wyrównała braki i stworzyła sztuczną nadwyżkę. Środki z funduszu, mimo że wpisane do budżetu JST jako własne, mogą zostać przeznaczone tylko na inwestycje. Nie można nimi pokryć bieżących potrzeb ani spłat kredytów, ale dzięki funduszom z RFIL samorządy mogły ograniczyć zaciąganie nowych długów. W 2019 r. deficyt budżetowy samorządów wynosił 1,7 mld zł, gdyby nie pomoc rządowa w $2020 \mathrm{r}$. deficyt osiągnąłby poziom 4,7 mld zł, gdyż wiele samorządów byłoby zmuszonych do zaciągnięcia długu na pokrycie planowanego deficytu budżetowego, ale dzięki dotacji nie było to konieczne lub zaciągnięty dług był niższy niż wcześniej zakładano (Gołaszewski, 2021). 
Zdaniem autora, taki deficyt wystąpiłby tylko w sytuacji, gdyby JST zrealizowały wszystkie planowane inwestycje mimo braku dotacji z RFIL. Trzeba jednak pamiętać, że brak możliwości pozyskania środków z RFIL mógłby spowodować rezygnację z części inwestycji lub przesunięcie ich na okresy późniejsze. Wówczas deficyt nie osiągnąłby wskazanego przez M. Gołaszewskiego poziomu ponad $4 \mathrm{mld}$ zł. Bez dodatkowych danych i badań nie jest możliwe oszacowanie poziomu deficytu przy braku środków z RFIL. Ponadto należy zaznaczyć, że środki z RFIL niewykorzystane przechodzą na lata następne, a w analizowanym $2020 \mathrm{r}$. zwiększają poziom wykazywanej przez JST nadwyżki. W tej sytuacji należy uznać, że wykazana nadwyżka finansowa jest zawyżona przez tę część środków RFIL, a ocena sytuacji JST bez odpowiednich korekt jest myląca. Środki uzyskane przez JST z RFIL zwiększają dochody, które wzrosły w 2020 r. o 9,5\% w stosunku do roku 2019. Pomijając środki z RFIL wzrost dochodów wyniósłby w tym okresie $5,8 \%$, czyli byłby blisko dwukrotnie niższy niż wzrost w 2019 r., kiedy to wyniósł 10,6\%.

Zgodnie z wypowiedziami ekspertów z Aesco Group ,[...] 5,6 mld zł nadwyżki brzmi jak ogromna kwota, jednak blednie przy przeszło 12 mld zł rat kredytów, pożyczek i obligacji, które samorządy miały do pokrycia w $2020 \mathrm{r}$. Spłaty te zostały w dużej mierze pokryte nowym długiem. Porównując planowane i wykonane dochody bieżące w 2019 i 2020 r. można zauważyć istotne pogorszenie sytuacji finansowej. W 2019 r. dochody bieżące były większe niż plan o $10,4 \%$, a w 2020 tylko o 3,8\%, co jest wartością zbliżoną do poziomu inflacji. [...] można postawić tezę, że samorządy w 2020 r. utraciły $17 \mathrm{mld}$ z dochodów bieżących" (Gołaszewski, 2021).

Zdaniem autora nie można wyciągać takich wniosków na podstawie analizy tylko dwóch okresów sprawozdawczych roku 2019 i 2020 . Taki wniosek byłby uzasadniony, gdyby wynikał z analizy co najmniej pięciu pełnych lat oraz/lub identyfikował wszystkie czynniki powodujące odchylenia od realizacji planu. Dopiero zaobserwowanie stałej praktyki zaniżania planów dochodowych o stały procent pozwoliłoby na wniosek, że pandemia COVID-19 spowodowała określoną zmianę realizacji planu przez obniżenie dochodów JST. Ponadto należałoby oczyścić dane o zmniejszenie dochodów spowodowane bezpośrednio obniżką PIT o 1\% i zwolnieniem z PIT osób do 26 roku życia oraz o wpływy z dotacji na program „Rodzina 500+” i innych czynników zakłócających planowanie. Natomiast jak spojrzymy na dane zaprezentowane w tabeli 2 to należy zauważyć, że nie występuje opisana powyżej zależność, a dane prognostyczne są bardzo zmienne w stosunku do późniejszej realizacji.

Tabela 2. Zestawienie planów i wykonania dochodów bieżących w latach 2015-2020

\begin{tabular}{|l|r|r|r|r|r|r|}
\hline \multicolumn{1}{|c|}{ Wyszczególnienie } & \multicolumn{1}{c|}{$\mathbf{2 0 1 5}$} & \multicolumn{1}{c|}{$\mathbf{2 0 1 6}$} & \multicolumn{1}{c|}{$\mathbf{2 0 1 7}$} & \multicolumn{1}{c|}{$\mathbf{2 0 1 8}$} & \multicolumn{1}{c|}{$\mathbf{2 0 1 9}$} & \multicolumn{1}{c|}{$\mathbf{2 0 2 0}$} \\
\hline Plan & $\mathbf{1 6 8} \mathbf{2 7 0}$ & $\mathbf{1 7 0 ~ 1 7 0}$ & $\mathbf{1 7 3 ~ 8 4 0}$ & $\mathbf{2 1 7} \mathbf{0 2 8}$ & $\mathbf{2 3 1} \mathbf{0 0 9}$ & $\mathbf{2 6 3 3 7 9}$ \\
\hline $\begin{array}{l}\text { przyrosty \% } \\
\text { (do roku poprzedniego) }\end{array}$ & $-0,6 \%$ & $1,1 \%$ & $2,2 \%$ & $24,8 \%$ & $6,4 \%$ & $14,0 \%$ \\
\hline Wykonanie & $\mathbf{1 7 6 ~ 0 7 0}$ & $\mathbf{2 0 0 7 3 0}$ & $\mathbf{2 1 6 1 3 0}$ & $\mathbf{2 2 9} 6 \mathbf{6 3 0}$ & $\mathbf{2 5 3 3 1 2}$ & $\mathbf{2 7 1 ~ 8 7 3}$ \\
\hline $\begin{array}{l}\text { przyrosty \% } \\
\text { (do roku poprzedniego) }\end{array}$ & $2,5 \%$ & $14,0 \%$ & $7,7 \%$ & $6,3 \%$ & $10,3 \%$ & $7,3 \%$ \\
\hline procent realizacji planu & $\mathbf{1 0 4 , 6 \%}$ & $\mathbf{1 1 7 , 9 \%}$ & $\mathbf{1 2 4 , 3 \%}$ & $\mathbf{1 0 5 , 8 \%}$ & $\mathbf{1 0 9 , 7 \%}$ & $\mathbf{1 0 3 , 2 \%}$ \\
\hline
\end{tabular}

Źr ódło: Opracowanie własne na podstawie danych Ministerstwa Finansów (2020 i 2018). 
W latach 2018-2020 dochody bieżące jednostek samorządu terytorialnego były wyższe od wydatków bieżących. Dochody bieżące w 2020 r. wzrosły w stosunku do roku wcześniejszego o 18,5 mld zł (7,3\%), a wydatki bieżące o 21,3 mld zł (9,3\%). Taki obraz sytuacji finansowej samorządów jest jednak zbyt optymistyczny, należy wziąć pod uwagę to, że od roku 2016 samorządy stały się wykonawcami programów socjalnych (w szczególności programu „Rodzina 500+”), z którego pieniądze zwiększają dochody własne (zwiększają dotacje celowe). Przyjmując, że samorządy nie dopłacają z własnych środków do obsługi programu, to dotacje te w żaden sposób nie zwiększają ich zdolności do wykonywania innych zadań, a tym samym nie poprawiają ich sytuacji finansowej. Samorząd jest wyłącznie wykonawcą, który nie ma wpływu na cele ani sposoby realizacji programu (jest wyłącznie pośrednikiem przy wypłatach środków dla beneficjentów). Dlatego rozpatrując sytuację dochodową należy wyłączyć z dochodów wpływy z dotacji na program „Rodzina 500+”.

Tabela 3. Dochody i wydatki JST skorygowane o program „Rodzina 500+”

\begin{tabular}{|c|c|c|c|c|c|c|c|}
\hline \multirow{3}{*}{ Wyszczególnienie } & \multicolumn{3}{|c|}{ Wykonanie } & \multicolumn{2}{|c|}{$\begin{array}{c}\text { Zmiana } \\
\text { wartościowo }\end{array}$} & \multicolumn{2}{|c|}{$\begin{array}{c}\text { Zmiana } \\
\text { procentowo }\end{array}$} \\
\hline & 2018 & 2019 & 2020 & $2019 / 18$ & $2020 / 19$ & $2019 / 18$ & $2020 / 19$ \\
\hline & \multicolumn{3}{|c|}{ mld zł } & \multicolumn{2}{|c|}{ mld zł } & \multicolumn{2}{|c|}{$\%$} \\
\hline 1 & 2 & 3 & 4 & $\begin{array}{c}\mathbf{5} \\
\text { (kol. 3-2) }\end{array}$ & $\begin{array}{c}\mathbf{6} \\
\text { (kol. 4-3) }\end{array}$ & $\begin{array}{c}7 \\
\text { (kol. 5/2) }\end{array}$ & $\begin{array}{c}\mathbf{8} \\
(\text { kol. 6/3) }\end{array}$ \\
\hline $\begin{array}{l}\text { Dochody ogólem } \\
\text { (bez korekt) }\end{array}$ & 251846 & 278507 & 304930 & 26661 & 26423 & 10,6 & 9,5 \\
\hline $\begin{array}{l}\begin{array}{l}\text { I. Dochody ogólem } \\
\text { (skorygowane*) }\end{array} \\
\end{array}$ & 229089 & 247344 & 263730 & 18256 & 16386 & 8,0 & 6,6 \\
\hline $\begin{array}{l}\text { I.1. Dochody } \\
\text { bieżące * }\end{array}$ & 206872 & 222150 & 230673 & 15277 & 8524 & 7,4 & 3,8 \\
\hline $\begin{array}{l}\text { I.2. Dochody } \\
\text { majątkowe }\end{array}$ & 22216 & 25195 & 33057 & 2979 & 7862 & 13,4 & 31,2 \\
\hline $\begin{array}{l}\text { Wydatki ogólem } \\
\text { (bez korekt) }\end{array}$ & 259386 & 280209 & 299241 & 20823 & 19032 & 8,0 & 6,8 \\
\hline $\begin{array}{l}\text { II. Wydatki } \\
\text { ogólem } \\
\text { (skorygowane**) }\end{array}$ & 236628 & 249046 & 258041 & 12418 & 8994 & 5,2 & 3,6 \\
\hline $\begin{array}{l}\text { II.1. Wydatki } \\
\text { bieżąace ** }\end{array}$ & 183750 & 197994 & 209289 & 14244 & 11295 & 7,8 & 5,7 \\
\hline $\begin{array}{l}\text { II.2. Wydatki } \\
\text { majątkowe }\end{array}$ & 52878 & 51052 & 48752 & -1826 & -2301 & $-3,5$ & $-4,5$ \\
\hline $\begin{array}{l}\text { Dotacje celowe na } \\
\text { program } \\
\text { „Rodzina 500+” }\end{array}$ & 22757 & 31163 & 41200 & 8406 & 10037 & 36,9 & 32,2 \\
\hline
\end{tabular}

* dochody skorygowane o dotacje celowe na program Rodzina 500+

** wydatki skorygowane o wydatki na program Rodzina 500+

Źródło: Opracowanie własne na podstawie danych opublikowanych na stronach Ministerstwa Finansów (2020). 
Zatem dochody bieżące po odjęciu 500+ nie wzrosły o 7,3\%, lecz po korekcie o 3,8\%, natomiast dochody ogółem wzrosły po korekcie o $6,6 \%$, a nie o $9,5 \%$, co w rzeczywistości przedstawia znacznie mniej korzystną sytuację finansową JST. Przy ocenie należy pamiętać, że w 2020 r. wzrosły koszty, które samorządy muszą ponosić, ponieważ rząd narzucił na JST sporo nowych obowiązków związanych z pandemią (m.in. dodatkowe wydatki na dezynfekcję przestrzeni publicznych, opiekę zdrowotną, maseczki, odzież ochronną, sprzęt medyczny, środki odkażające dla szpitali, noclegi i wyżywienie dla medyków, opiekę nad osobami starszymi, pomoc dla przedsiębiorców, wsparcie szkół).

Zjawiskiem, które najlepiej ilustruje pogorszenie kondycji finansowej samorządów, jest spadek nadwyżki operacyjnej. Jest to różnica między bieżącymi dochodami i wydatkami, która nie uwzględnia konieczności spłaty zadłużenia. Nadwyżka budżetowa wynika także z poziomu wydatków inwestycyjnych, które w każdym roku są inne i z których zrezygnować jest względnie prosto. O ile w 2019 r. łączna nadwyżka operacyjna dochodów bieżących nad wydatkami bieżącymi wynosiła 24,1 mld zł (9,5\% dochodów bieżących), o tyle w roku 2020 było to $21,4 \mathrm{mld}$ zł (7,9\% dochodów bieżących). Nastąpił spadek wyniku operacyjnego w stosunku do roku poprzedniego o 11,5\% (kwotowo ubytek o 2,7 mld zł). Zmniejszenie wyniku operacyjnego w 2020 r. należy uznać za znaczne, gdyż uzyskany wynik jest niższy nawet od nadwyżki operacyjnej z 2018 r. o 1,7 mld (czyli spadek o 7,5\%).

Na potencjał rozwojowy JST składają się trzy elementy: potencjał własny, czyli nadwyżka operacyjna, wsparcie zewnętrzne, czyli dotacje oraz finansowanie zwrotne, uzależnione od zdolności kredytowej i od możliwości obsługi długu (zależna od relacji nadwyżki operacyjnej do dochodów bieżących bez dotacji). Jak wynika z obliczeń ekspertów Związku Miast Polskich, w porównaniu z rekordowym pod względem poziomu inwestycji rokiem 2018 (52,8 mld zł) plan na 2019 r. był jeszcze wyższy ( 65 mld zł), jednak został wykonany w kwocie tylko 51,1 mld zł. Natomiast w 2020 r. sytuacja się jeszcze pogorszyła, wykonano 48,7 mld zł (przy planie 57,3 mld zł). Coroczny spadek inwestycji wskazuje wyraźnie na pogorszenie możliwości inwestycyjnych, a jeżeli tendencja się utrzyma wpłynie na dalsze zahamowanie rozwoju lokalnego i regionalnego. Ryzyko to jest tym większe, że malejące inwestycje samorządowe to dodatkowy czynnik zmniejszający wpływy z podatków VAT, CIT i finalnie PIT (oprócz pandemii i pozostałych czynników).

\subsection{Sytuacja dochodowa}

Rok 2020 jest okresem znaczącego pogorszenia struktury dochodów JST: zmniejszenia roli dochodów własnych, zwłaszcza podatkowych i zwiększenia roli dochodów transferowych. Efekt ten wywołują trzy nakładające się na siebie zjawiska. Po pierwsze, ubiegłoroczne zmiany w PIT (obniżenie stawek z 18\% do 17\%, podwyższenie kosztów uzyskania przychodów dla pracowników oraz wprowadzenie zerowego PIT-u dla osób poniżej 26 roku życia), które bez rekompensaty zmniejszyły dochody JST z udziałów w PIT. Po drugie, dalsze zmniejszenie dochodów podatkowych w wyniku lockdownu i kryzysu gospodarczego. Po trzecie, reakcja rządu na kryzys, jakim był wybór wsparcia dla samorządów w formule dotacji (RFIL). Zapowiadane na przyszły rok zmiany w podatkach dochodowych przyniosą dalsze i znaczące wzmocnienie tego trendu. 
Tabela 4. Dochody JST według podstawowych źródeł w latach 2018-2020

\begin{tabular}{|c|c|c|c|c|c|c|c|}
\hline \multirow{3}{*}{ Wyszczególnienie } & \multicolumn{3}{|c|}{ Wykonanie } & \multicolumn{2}{|c|}{ Zmiana wartościowo } & \multicolumn{2}{|c|}{ Zmiana procentowo } \\
\hline & 2018 & 2019 & 2020 & $\begin{array}{l}2019 / \\
2018\end{array}$ & $\begin{array}{l}2020 / \\
2019\end{array}$ & $\begin{array}{l}2019 / \\
2018\end{array}$ & $\begin{array}{l}2020 / \\
2019\end{array}$ \\
\hline & \multicolumn{3}{|c|}{ w mln zł } & \multicolumn{2}{|c|}{$\mathrm{w} \mathrm{mln} \mathrm{zl}$} & \multicolumn{2}{|c|}{$\mathrm{w} \%$} \\
\hline 1 & 2 & 3 & 4 & \begin{tabular}{|c|}
$\mathbf{5}$ \\
$(\mathrm{kol} .3-2)$
\end{tabular} & $\begin{array}{c}\mathbf{6} \\
\text { (kol. 4-3) }\end{array}$ & $\begin{array}{c}7 \\
\text { (kol. 5/2) }\end{array}$ & $\begin{array}{c}\mathbf{8} \\
\text { (kol. 6/3) }\end{array}$ \\
\hline Dochody ogółem & 251846 & 278507 & 304930 & 26661 & 26423 & 10,6 & 9,5 \\
\hline $\begin{array}{l}\text { 1. Dochody wlasne, } \\
\text { w tym: }\end{array}$ & 124042 & 135769 & 146356 & 11726 & 10588 & 9,5 & 7,8 \\
\hline PIT & 50908 & 56140 & 55078 & 5232 & -1063 & 10,3 & $-1,9$ \\
\hline CIT & 9698 & 10902 & 11325 & 1204 & 424 & 12,4 & 3,9 \\
\hline $\begin{array}{l}\text { podatek } \\
\text { od nieruchomości }\end{array}$ & 22617 & 23299 & 24216 & 682 & 917 & 3,0 & 3,9 \\
\hline $\begin{array}{l}\text { pozostałe dochody } \\
\text { podatkowe i z opłat JST }\end{array}$ & 7081 & 7399 & 7487 & 319 & 88 & 4,5 & 1,2 \\
\hline dochody z majątku & 7700 & 7493 & 8023 & -207 & 530 & $-2,7$ & 7,1 \\
\hline pozostałe dochody & 26038 & 30535 & 40227 & 4497 & 9692 & 17,3 & 31,7 \\
\hline 2. Subwencja, w tym: & 56430 & 61746 & 67029 & 5316 & 5284 & 9,4 & 8,6 \\
\hline oświatowa & 43075 & 46899 & 50157 & 3824 & 3257 & 8,9 & 6,9 \\
\hline 3. Dotacje, w tym: & 71375 & 80993 & 91544 & 9618 & 10551 & 13,5 & 13,0 \\
\hline $\begin{array}{l}\text { na zadania } \\
\mathrm{z} \text { adm. rządowej }\end{array}$ & 43903 & 53203 & 63721 & 9300 & 10518 & 21,2 & 19,8 \\
\hline
\end{tabular}

Źródło: Opracowanie własne na podstawie danych opublikowanych na stronach Ministerstwa Finansów (2020).

Ogólnie w 2020 r. w stosunku do roku 2019 dochody własne wzrosły o 7,8\% (10,6 mld zł). Spadły jednak dochody podatkowe z PIT o 1,06 mld zł (spadek o 1,9\%), w stosunku do 2019 r., natomiast wpływy z podatku CIT zwiększyły się o 3,9 proc. w stosunku do roku ubiegłego. Łączne dochody podatkowe (PIT, CIT, podatek od nieruchomości i pozostałe podatki) wzrosły o 0,36 mld zł, czyli łącznie dochody podatkowe wzrosły o 3,7\% w stosunku do 2019 r. W tym samym czasie subwencje i dotacje wzrosły o 8,6\% i 13,0\%, co pokazuje rosnące uzależnienie samorządów od finansowania z budżetu centralnego - dochody własne rosną wolniej niż w latach poprzednich o 1,7 p.p., gdy wzrost subwencji i dotacji wyhamował tylko o 0,8 i 0,5 p.p. Wśród dochodów subwencyjnych wzrosła przede wszystkim część oświatowa subwencji: o 6,9\% (3,3 mld zł), co wiąże się z prawną podwyżką wynagrodzeń nauczycielskich, a wśród dochodów dotacyjnych wzrosły przede wszystkim dotacje na zadania zlecone z zakresu administracji rządowej o 10,5 mld zł (wzrost o 19,8\%). 


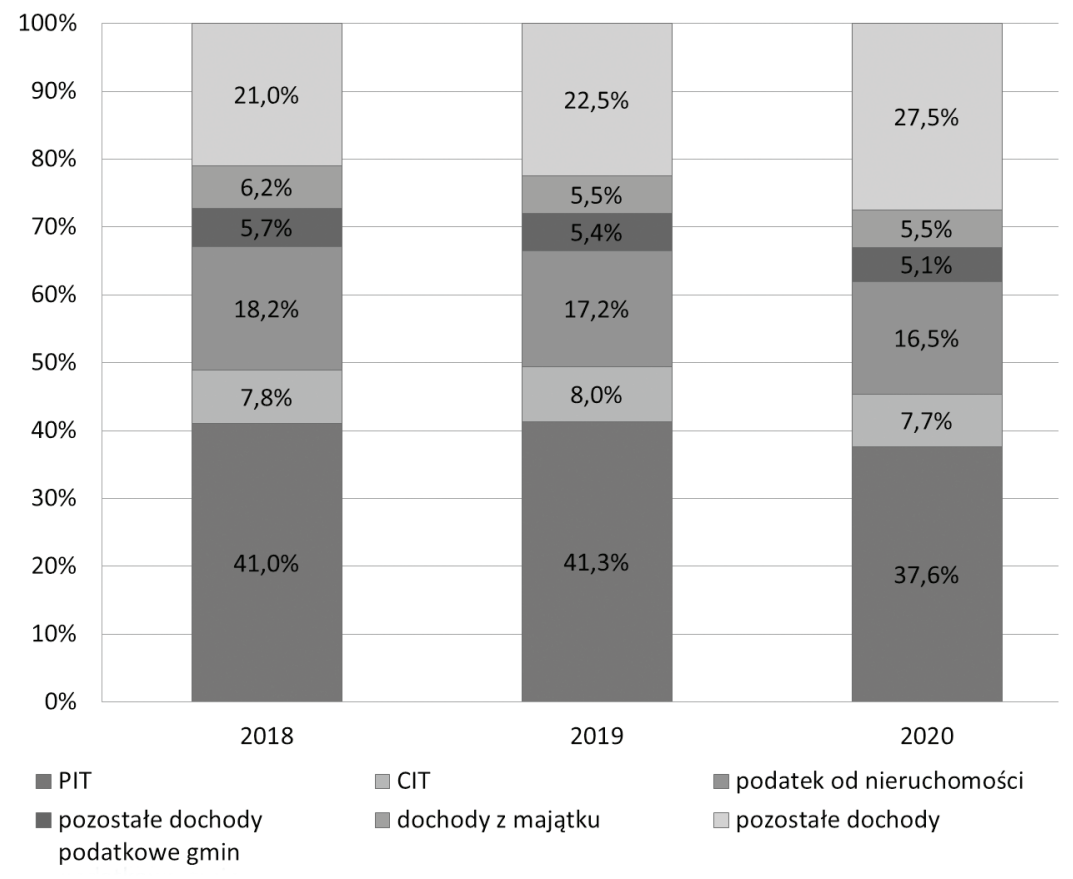

Rysunek 1. Struktura dochodów własnych JST w latach 2018-2020

Źródło: opracowanie własne.

W dochodach własnych główne źródło to podatek PIT oraz podatek od nieruchomości. Istotny jest również podatek CIT i dochody z majątku, które są łatwe w planowaniu, choć bardzo uzależnione od koniunktury gospodarczej. Pozostałe podatki i opłaty mają udział łączny na poziomie niższym, niż sam podatek CIT. W tej sytuacji zmniejszenie się udziału w dochodach tych głównych pozycji jest bardzo niepokojące i groźne dla przyszłej sytuacji finansowej samorządów. Biorąc to pod uwagę, niepokojące są zmiany w strukturze dochodów własnych. Wszystkie najważniejsze dochody JST zmniejszyły swój udział w dochodach własnych (najwięcej dochody z PIT, których udział spadł do 37,6\% o 3,7 p.p.). Udział dochodów z majątku pozostał stały: 5,5\%. Wzrósł natomiast udział pozostałych dochodów aż o 5,0 p.p. do 27,5\%. W pozycji tej znajdują się m.in. dochody z RFIL, które w kolejnym roku będą 3 razy niższe i nie wiadomo, czy pojawią się inne dochody rekompensujące ten ubytek. Nie świadczy to o stabilności sytuacji dochodowej samorządów i przy utrzymaniu się negatywnych tendencji może prowadzić do poważnych kłopotów finansowych wielu jednostek samorządowych. 


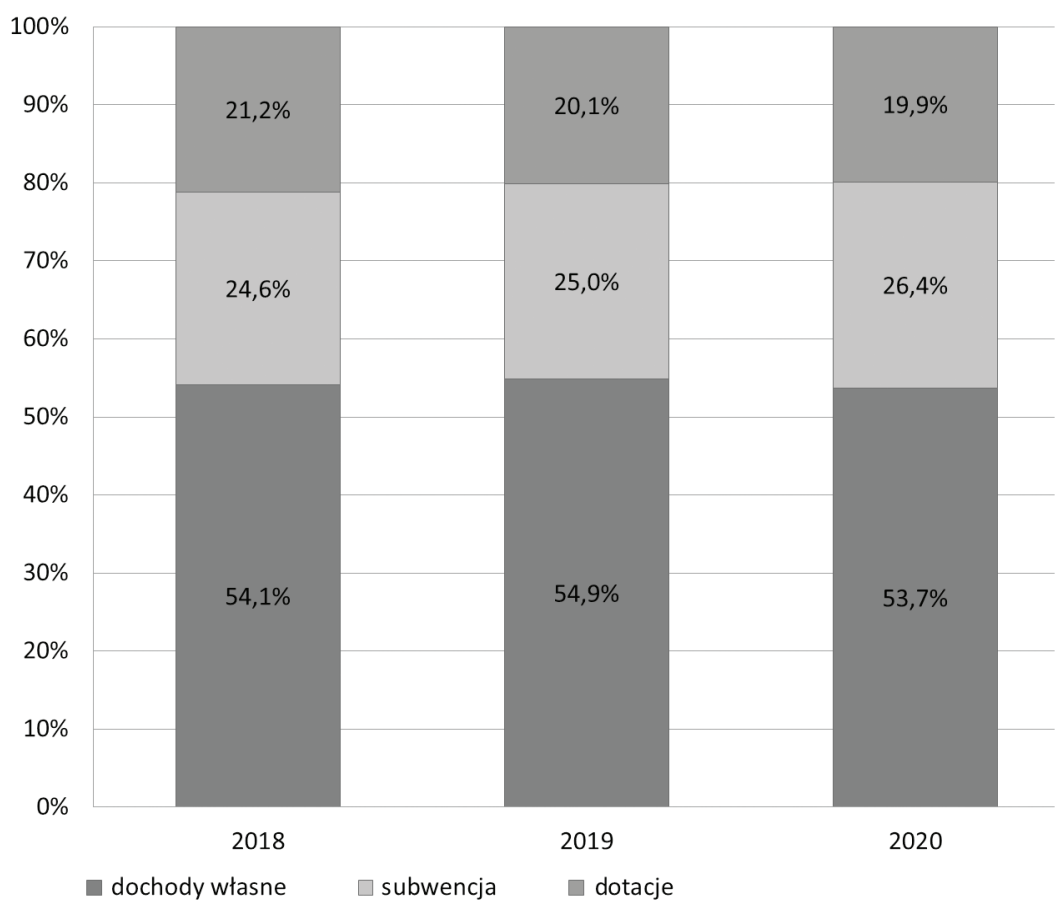

Rysunek 2. Struktura dochodów samorządów w latach 2018-2020 skorygowana o dotacje na program „Rodzina 500+” i dochody z RFIL

Źr ódło: opracowanie własne.

Wyliczenia struktury dochodów ogółem przeprowadzono po korekcie dochodów o dotacje na program „Rodzina 500+” oraz o dochody z RFIL. Samorządy są wyłącznie wykonawcą transferów 500+, a dochody i wydatki z tego tytułu nie wpływają w żaden sposób ani na sytuację samorządów, ani na realizowane przez nie usługi dla ludności. Środki uzyskane z RFIL są natomiast jednorazowe w wysokości 13 mld zł (10,3 mld w 2020, a pozostała część w 2021). W latach 2018-2020 w strukturze dochodów JST największą kategorią po korektach były dochody własne, które w 2020 r. stanowiły 53,7\% dochodów ogółem (spadek udziału o 1,2 p.p. w stosunku do 2019 r. $)^{4}$. W tym samym roku udział dotacji ogółem zmalał tylko o 0,2 p.p. do poziomu 19,1\%. Udział subwencji ogólnej w dochodach ogółem JST w 2020 r. wyniósł $26,4 \%$ (wzrost o 1,4 p.p.). Potwierdza to przewidywany spadek udziału dochodów własnych w dochodach JST, co może wpływać na ograniczanie ich samodzielności.

\footnotetext{
${ }^{4}$ Dane skorygowane o dotacje na program „Rodzina 500+”.
} 


\subsection{Zmiany wielkości i struktury dochodów w różnych grupach samorządów}

Dane dotyczące ogólnej sytuacji finansowej i dochodowej sektora samorządowego pokazują, że nie jest tak dobrze, jak prezentują to władze centralne, ale też sytuacja nie jest tak zła, jak opisują to samorządowcy i analitycy. Grupa jednostek samorządowych jest zróżnicowana zarówno pod względem wielkości, jak zadań i kompetencji (gminy, powiaty, miasta na prawach powiatu i województwa), a w ramach poszczególnych grup sytuacja może wyglądać bardzo różnie.

Dochody ogółem wzrosły o 9,5\% w 2020 r. i wzrost ten był podobny do uzyskanego w 2019 r. W 2020 r. dochody gmin wzrosły o 10,3\%, a powiatów i województw o odpowiednio $12,6 \%$ i $11,77 \%$. Na tym tle wyjątkowo słabe wyniki uzyskały miasta na prawach powiatu (miasta na p.p.), których dochody ogółem wzrosły tylko o 6,8\%. W 2019 r. dynamika zmian dochodów ogółem była podobna dla wszystkich czterech wyodrębnionych grup, a wzrosty dochodów kształtowały się na poziomie 9,8-11,3\%. Takie zmiany trudno wyjaśniać zmianą sytuacji gospodarczej czy pandemią COVID-19. Natomiast pośrednio wpływy te mogą mieć miejsce. Sama dotacja z RFIL wyniosła ponad 10 mld w 2020 r., lecz nie została równomiernie podzielona na JST.

Tabela 5. Dochody ogółem według kategorii JST w latach 2018-2020

\begin{tabular}{|c|c|c|c|c|c|c|c|}
\hline \multirow{3}{*}{ Wyszczególnienie } & \multicolumn{3}{|c|}{ Wykonanie } & \multicolumn{2}{|c|}{$\begin{array}{c}\text { Zmiana } \\
\text { wartościowo }\end{array}$} & \multicolumn{2}{|c|}{ Zmiana procentowo } \\
\hline & 2018 & 2019 & 2020 & 2019/18 & $2020 / 19$ & $2019 / 18$ & $2020 / 19$ \\
\hline & \multicolumn{3}{|c|}{ w mln zł } & \multicolumn{2}{|c|}{$\mathrm{w}$ mln $\mathrm{zl}$} & \multicolumn{2}{|c|}{$\mathrm{w} \%$} \\
\hline 1 & 2 & 3 & 4 & $\begin{array}{c}\mathbf{5} \\
\text { (kol. 3-2) }\end{array}$ & $\begin{array}{c}\mathbf{6} \\
\text { (kol. 4-3) }\end{array}$ & $\begin{array}{c}7 \\
\text { (kol. 3/2) }\end{array}$ & $\begin{array}{c}\mathbf{8} \\
\text { (kol. 4/3) }\end{array}$ \\
\hline $\begin{array}{l}\text { DOCHODY OGÓLEM } \\
\text { dla JST }\end{array}$ & 251846 & 278507 & 304930 & 26661 & 26423 & 10,6 & 9,5 \\
\hline gminy & 121426 & 135162 & 149090 & 13736 & 13929 & 11,3 & 10,3 \\
\hline powiaty & 27959 & 30696 & 34569 & 2737 & 3872 & 9,8 & 12,6 \\
\hline miasta na p.p. & 85508 & 93894 & 100314 & 8387 & 6420 & 9,8 & 6,8 \\
\hline województwa & 16954 & 18755 & 20957 & 1801 & 2202 & 10,6 & 11,7 \\
\hline
\end{tabular}

Źród ło: Opracowanie własne na podstawie danych opublikowanych na stronach Ministerstwa Finansów (2020)

Opisane zjawisko jeszcze bardziej widoczne jest w przypadku dochodów bieżących, która to kategoria jest najważniejsza w ocenie sytuacji JST i ich zdolności do rozwoju i finansowania inwestycji. Dochody bieżące JST wzrosły w 2020 r. zdecydowanie mniej niż dochody ogółem, bo tylko o 7,3\% (wobec 9,5\% wzrostu dochodów ogółem). Jak widać w poniższej tabeli w 2019 r., dochody bieżące rosły we wszystkich jednostkach w prawie takim samym tempie od $9,6 \%$ do $10,8 \%$, natomiast w 2020 rozrzut był duży od 4,9\% w miastach na p.p. do 12,3\% w województwach. Dochody bieżące gmin i powiatów wzrosły w tym czasie odpowiednio o 7,9\% i 9,7\%. Różnice te należy uznać za bardzo znaczące, szczególnie na tle 2019 r., gdy kształtowały się na zbliżonym poziomie. 
Tabela 6. Dochody bieżące według kategorii JST w latach 2018-2020

\begin{tabular}{|c|c|c|c|c|c|c|c|}
\hline \multirow{3}{*}{ Wyszczególnienie } & \multicolumn{3}{|c|}{ Wykonanie } & \multicolumn{2}{|c|}{$\begin{array}{c}\text { Zmiana } \\
\text { wartościowo }\end{array}$} & \multicolumn{2}{|c|}{$\begin{array}{c}\text { Zmiana } \\
\text { procentowo }\end{array}$} \\
\hline & 2018 & 2019 & 2020 & $2019 / 18$ & $2020 / 19$ & $2019 / 18$ & $2020 / 19$ \\
\hline & \multicolumn{3}{|c|}{$\mathrm{w} \mathrm{mln} \mathrm{zl}$} & \multicolumn{2}{|c|}{$\mathrm{w} \mathrm{mln} \mathrm{zl}$} & \multicolumn{2}{|c|}{ W \% } \\
\hline 1 & 2 & 3 & 4 & $\begin{array}{c}\mathbf{5} \\
\text { (kol. 3-2) }\end{array}$ & $\begin{array}{c}\mathbf{6} \\
\text { (kol. 4-3) }\end{array}$ & $\begin{array}{c}7 \\
\text { (kol. 3/2) }\end{array}$ & $\begin{array}{c}\mathbf{8} \\
\text { (kol. 4/3) }\end{array}$ \\
\hline $\begin{array}{l}\text { DOCHODY BIEŻĄCE } \\
\text { dla JST }\end{array}$ & 229630 & 253312 & 271873 & 23682 & 18561 & 10,3 & 7,3 \\
\hline gminy & 111706 & 123796 & 133620 & 12091 & 9823 & 10,8 & 7,9 \\
\hline powiaty & 24732 & 27103 & 29738 & 2372 & 2635 & 9,6 & 9,7 \\
\hline miasta na p.p. & 79473 & 87331 & 91583 & 7858 & 4252 & 9,9 & 4,9 \\
\hline województwa & 13720 & 15081 & 16932 & 1361 & 1851 & 9,9 & 12,3 \\
\hline
\end{tabular}

Źr ódło: Opracowanie własne na podstawie danych opublikowanych na stronach Ministerstwa Finansów (2020)

Potwierdzeniem pogorszającej się sytuacji finansowej samorządów są zmiany nadwyżki bieżącej. W 2019 zmniejszenie nadwyżki bieżącej zanotowały tylko miasta na p.p. (o ponad 11\%), ale w 2020 nadwyżka bieżąca była niższa niż rok wcześniej już we wszystkich grupach samorządów oprócz województw. Rekordowy spadek na poziomie blisko 48\% zanotowały znowu miasta na prawach powiatu, a w przypadku gmin i powiatów był to spadek o $1,9 \%$. Zmniejszenie nadwyżki było efektem nie tylko wolniejszego wzrostu dochodów, ale również pojawieniem się dodatkowych kosztów związanych z pandemią, o których już była mowa. Ponadto nie wszystkie koszty można w prosty sposób obniżyć przy słabnącej koniunkturze.

Tabela 7. Nadwyżka bieżąca według kategorii JST w latach 2018-2020

\begin{tabular}{|c|c|c|c|c|c|c|c|}
\hline \multirow{3}{*}{ Wyszczególnienie } & \multicolumn{3}{|c|}{ Wykonanie } & \multicolumn{2}{|c|}{$\begin{array}{c}\text { Zmiana } \\
\text { wartościowo }\end{array}$} & \multicolumn{2}{|c|}{$\begin{array}{c}\text { Zmiana } \\
\text { procentowo }\end{array}$} \\
\hline & 2018 & 2019 & 2020 & $2019 / 18$ & $2020 / 19$ & $2019 / 18$ & $2020 / 19$ \\
\hline & \multicolumn{3}{|c|}{ w mln zł } & \multicolumn{2}{|c|}{ w mln zł } & \multicolumn{2}{|c|}{$\mathrm{w} \%$} \\
\hline 1 & 2 & 3 & 4 & $\begin{array}{c}\mathbf{5} \\
\text { (kol. 3-2) }\end{array}$ & $\begin{array}{c}\mathbf{6} \\
\text { (kol. 4-3) }\end{array}$ & $\begin{array}{c}7 \\
(\text { kol. 3/2) }\end{array}$ & $\begin{array}{c}\mathbf{8} \\
(\text { kol. 4/3) }\end{array}$ \\
\hline Wyniki bieżące ogółem JST & 23122 & 24156 & 21384 & 1034 & -2771 & 4,5 & $-11,5$ \\
\hline Gminy & 10815 & 11377 & 11155 & 562 & -222 & 5,2 & $-1,9$ \\
\hline Powiaty & 2058 & 2762 & 2711 & 704 & -52 & 34,2 & $-1,9$ \\
\hline $\begin{array}{l}\text { miasta } \\
\text { na prawach powiatu }\end{array}$ & 7162 & 6343 & 3307 & -819 & -3037 & $-11,4$ & $-47,9$ \\
\hline Województwa & 3088 & 3673 & 4212 & 586 & 539 & 19,0 & 14,7 \\
\hline
\end{tabular}

Źr ód ło: Opracowanie własne na podstawie danych opublikowanych na stronach Ministerstwa Finansów (2020) 


\section{Zakończenie}

Na podstawie powyższych rozważań nie widać dramatycznego pogorszenia sytuacji finansowej jednostek samorząa terytorialnego, ale też nie widać w prezentowanych danych uzasadnienia dla optymizmu władz centralnych w tej kwestii. JST stanęły przed ogromnymi wyzwaniami organizacyjnymi i finansowymi. Po raz pierwszy zagrożenie wirusem ma tak istotny wpływ zarówno na społeczeństwo i gospodarkę, jak i na administrację publiczną wszystkich szczebli. Rozległość obowiązków, nowych zadań i zmian legislacyjnych, które objęły samorząady, z pewnością zmusiła je do wzmożonej pracy. Ogólny stan sektora samorządowego w 2020 r. można podsumować następująco:

- Dochody JST wzrosły w stosunku do poprzedniego roku mniej niż zakładano.

- Koszty związane z pandemią spowodowały dodatkowe zmniejszenie nadwyżki bieżącej JST.

- Na poziomie zbiorczym nie widać bezpośredniego zagrożenia dla płynności finansowej samorządów, chociaż nie można wykluczyć trudnej sytuacji poszczególnych jednostek oraz problemów z płynnością w większej skali, jeżeli utrzymają się negatywne tendencje.

- Dane zbiorcze są zniekształcone przez czynniki zakłócające, jak środki z RFIL (ujęte w dochodach własnych) czy dotacje na program Rodzina 500+. Oznacza to, że sytuacja finansowa JST jest zdecydowanie mniej korzystna, niż wynika to z danych zbiorczych.

Samorządy są ważnym inwestorem publicznym, a inwestycje publiczne to jedno z podstawowych narzędzi, za pomocą których można sobie radzić z kryzysami gospodarczymi. Gdyby inwestycje się załamały, to byłoby to groźne nie tylko dla samorząáów, ale też dla całego kraju. Od kilku lat inwestycje JST są mniejsze od planowanych, a pandemia i wszystkie związane z nią konsekwencje wpływają negatywnie na poziom inwestycji samorządowych. Jeśli zatem JST nie dostaną wsparcia, to inwestycje nie będą mogły być utrzymane.

Zdaniem ekspertów szacuje się, że środki wypracowane przez samorządy, które miały zostać wykorzystane na inwestycje, będą niższe o co najmniej $7 \mathrm{mld}$ zł (Krawczyk, 2020). Spowoduje to odłożenie części inwestycji na później. Możliwe jest, że z części planowanych inwestycji samorządy zrezygnują trwale. Zmniejszenie inwestycji odczuje nie tylko gospodarka, ale również mieszkańcy bez względu na to, z czego zrezygnują samorządy w planach inwestycyjnych na kolejny rok lub dłużej. Mogą to być np. remonty dróg, budowa nowych szkół/przedszkoli/żłobków, inwestycje w kulturę, dofinansowania na rzecz edukacji czy opieki zdrowotnej.

Pozytywne jest to, że nie zrealizowały się czarne scenariusze. Samorządom udało się utrzymać nadwyżkę bieżącą, zrealizować większość planowanych dochodów i zapewnić prawidłowe funkcjonowanie większości usług publicznych na swoim terenie. Nie oznacza to jednak, biorąc pod uwagę ich ograniczone w porównaniu z władzami centralnymi możliwości, że bez wsparcia poradzą sobie w kolejnych latach ze skutkami epidemii. Wskazane są dalsze pogłębione badania dotyczące wpływu pandemii, w tym ankietowe, a szczególnie analiza długoterminowych negatywnych skutków pandemii w latach kolejnych oraz możliwości przeciwdziałania tym skutkom (metody wparcia samorządów). 


\section{Bibliografia}

Folczak, P., Gołaszewski, M. (2020). O ile spadna dochody JST w zwiazku z pandemia COVID-19? [online, dostęp: 2021-02-20]. Dostępny w Internecie: https://aesco.com.pl/dochody-jst-o-ile-spadna-w-zwiazkuz-pandemia-covid-19/.

Gołaszewski, M. (2020). Wptyw załamania gospodarczego zwiazanego z COVID-19 na finanse, sytuację zadlużeniowa i płynnościowa JST. [online, dostęp: 2021-03-20]. Dostępny w Internecie: http://www.kongresadministracji.pl/wp-content/uploads/2020/06/Konsekwencje-zatrzymania-gospodarki-dla-finansowjst-KZAS-06.2020-3.pdf

Gołaszewski, M. (2021). Samorządy z nadwyżka czy ukrytym deficytem? [online, dostęp: 2021-03-18]. Dostępny w Internecie: https:/www.miasta.pl/aktualnosci/samorzady-z-nadwyzka-czy-ukrytym-deficytem.

Izdebski, H. (2020). Tarcze Antykryzysowe - dokończenie budowy państwa PiS-u? Ustawodawstwo okresu pandemii a funkcjonowanie samorządu. [online, dostęp: 2021-03-20]. Dostępny w Internecie: https:// www.batory.org.pl/wp-content/uploads/2020/10/Tarcze-Antykryzysowe-dokończenie-budowy-państwaPIS-u.-Ustawodawstwo-okresu-pandemii-a-funkcjonowanie-samorzadu.pdf.

Krawczyk, B (2020). Pandemia uderza w budżety samorząów. Przegląd Komunalny 1/2021 (352) [online, dostęp: 2021-03-20]. Dostępny w Internecie: https://portalkomunalny.pl/plus/?art=Pandemia-uderza-w-budzety-samorzadow-26938.

Ministerstwo Finansów. (2020). Sprawozdania budżetowe. Zestawienia zbiorcze. Bazy danych. Informacja roczna. [online, dostęp: 2021-03-20]. Dostępny w Internecie: https://www.gov.pl/web/finanse/sprawozdania-budzetowe; https://www.gov.pl/web/finanse/zestawienia-zbiorcze3; https:/www.gov.pl/web/finanse/bazy-danych3; https://www.gov.pl/web/finanse/informacja-roczna3.

Ministerstwo Finansów. (2018). Sprawozdania budżetowe. [online, dostęp: 2021-03-20]. Dostępny w Internecie: https://mf-arch2.mf.gov.pl/web/bip/ministerstwo-finansow/dzialalnosc/finanse-publiczne/budzety-jednostek-samorzadu-terytorialnego/sprawozdania-budzetowe.

Nelicki, A. (2020). Wptyw ustawodawstwa okresu pandemii COVID-19 na finanse jednostek samorzadu terytorialnego [online, dostęp: 2021-20-03]. Warszawa: Fundacja im. Stefana Batorego. Dostępny w Internecie: https://www.batory.org.pl/wp-content/uploads/2020/11/Wpływ-ustawodawstwa-okresu-pandemiiCOVID-19-na-finanse-JST.pdf.

Swianiewicz, P., Łukomska, J. (2020a). Finanse samorzadu terytorialnego w dobie pandemii, Fundacja im. Stefana Batorego [online, dostęp: 2021-03-20]. Dostępny w Internecie: https://www.batory.org.pl/wp-content/uploads/2020/11/Finanse-samorzadu-w-dobie-pandemii.pdf.

Swianiewicz, P., Łukomska, J. (2020b). Ewolucja sytuacji finansowej samorzadów terytorialnych w Polsce po 2014 roku Fundacja im. Stefana Batorego [online, dostęp: 2021-03-20]. Dostępny w Internecie: https:// www.batory.org.pl/wp-content/uploads/2020/05/Ewolucja-sytuacji-finansowej-samorzadow_final.pdf.

Akty prawne:

Ustawa z dnia 27 sierpnia 2009 r. o finansach publicznych. T.j. Dz.U. z 2009 r., nr 157, poz. 1240, z późn. zm.

Ustawa z dnia 2 marca 2020 r. o szczególnych rozwiązaniach związanych z zapobieganiem, przeciwdziałaniem i zwalczaniem COVID-19, innych chorób zakaźnych oraz wywołanych nimi sytuacji kryzysowych. T.j. Dz.U. z 2020 r., poz. 374, z późń. zm.

Ustawa z dnia 31 marca 2020 r. o zmianie ustawy o szczególnych rozwiązaniach związanych z zapobieganiem, przeciwdziałaniem i zwalczaniem COVID-19, innych chorób zakazanych oraz wywołanych nimi sytuacji kryzysowych oraz niektórych innych ustaw. T.j. Dz.U. z 2020 r., poz. 568, z późń. zm.

Ustawa z dnia z 3 kwietnia 2020 r. o szczególnych rozwiązaniach wspierających realizację programów operacyjnych w związku z wystąpieniem COVID-19 w 2020 r. T.j. Dz.U. z 2020 r., poz. 694, z późń. zm.

Ustawa z dnia 16 kwietnia 2020 r. o szczególnych instrumentach wsparcia w związku z rozprzestrzenianiem się wirusa SARS-CoV-2. T.j. Dz.U. z 2020 r., poz. 695, z późń. zm.

Ustawa z dnia 14 maja 2020 r. o zmianie niektórych ustaw w zakresie działań osłonowych w związku z rozprzestrzenianiem się wirusa SARS-CoV-2. T.j. Dz.U. z 2020 r., poz. 875, z późń. zm.

Ustawa z dnia 19 czerwca 2020 r. o dopłatach do oprocentowania kredytów bankowych udzielanych przedsiębiorcom dotkniętym skutkami COVID-19 oraz o uproszczonym postępowaniu o zatwierdzenie układu w związku z wystąpieniem COVID-19. T.j. Dz.U. z 2020 r., poz. 1086, z późń. zm. 
Ustawa z dnia 19 czerwca 2020 r. o dodatku solidarnościowym przyznawanym w celu przeciwdziałania negatywnym skutkom COVID-19. T.j. Dz.U. z 2020 r., poz. 1068.

Ustawa z dnia 15 lipca 2020 r. o Polskim Bonie Turystycznym. T.j. Dz.U. z 2020 r., poz. 1262, z późń. zm.

Ustawa z dnia 16 lipca 2020 r. o udzielaniu pomocy publicznej w celu ratowania lub restrukturyzacji przedsiębiorców. T.j. Dz.U. z 2020 r., poz. 1298.

Ustawa z dnia 16 lipca 2020 r. o wsparciu rynku ubezpieczeń należności handlowych w związku z przeciwdziałaniem skutkom gospodarczym COVID-19. T.j. Dz.U. z 2020 r., poz. 1422.

Ustawa z dnia 17 września 2020 r. o zmianie ustawy o szczególnych rozwiązaniach związanych z zapobieganiem, przeciwdziałaniem i zwalczaniem COVID-19, innych chorób zakaźnych oraz wywołanych nimi sytuacji kryzysowych oraz niektórych innych ustaw. T.j. Dz.U. z 2020 r., poz. 1639.

Ustawa z dnia 9 grudnia 2020 r. o zmianie ustawy o szczególnych rozwiązaniach związanych z zapobieganiem, przeciwdziałaniem i zwalczaniem COVID-19, innych chorób zakaźnych oraz wywołanych nimi sytuacji kryzysowych oraz niektórych innych ustaw. T.j. Dz.U. z 2020 r., poz. 2255.

Ustawa z dnia 21 stycznia 2021 r. o zmianie ustawy o szczególnych rozwiązaniach związanych z zapobieganiem, przeciwdziałaniem i zwalczaniem COVID-19, innych chorób zakaźnych oraz wywołanych nimi sytuacji kryzysowych oraz niektórych innych ustaw. T.j. Dz.U. z 2021 r., poz. 159.

\title{
The impact of the COVID-19 Pandemic on local government entities selected problems
}

\begin{abstract}
The recession caused by the COVID-19 pandemic and the lockdown was the main factor affecting the financial situation of local government units in 2020. The epidemic posed a number of challenges for local government units and resulted in the need to quickly adapt their functioning to the new reality. The aim of the article is to assess the impact of a pandemic on the functioning of local government units (LGUs) and their financial situation. The problems resulting from the legislation on the functioning of local government units introduced and changed as a result of the pandemic, as well as the impact of the pandemic on

their financial situation are presented. The method of comparative analysis was used to assess changes in the financial situation of local government units. The basis for the analyzes was the income, expenditure and result figures for 2018-2020 and their comparison with the plans. The main source of data are the aggregate figures available at www.mf.gov.pl: collective statements on the implementation of local government budgets after four quarters of 2018, 2019 and 2020, supplemented in some matters with a reference to reports on the implementation of budgets Rb27s (income) and Rb28s (expenses).
\end{abstract}

Keywords: local authorities, financial situation, public finance, COVID-19 pandemic 